\title{
THE TRANSFORMATION OF RESIDENTIAL SPATIAL AND FORM IN KAUMAN VILLAGE YOGYAKARTA
}

Received February 15 ${ }^{\text {th }}, 2021 \mid$ Accepted September $7^{\text {th }}, 2021$ | Available online December 15 $5^{\text {th }}, 2021$ | DOI http://dx. doi. org/10.18860/jia.v6i4.11665 |

\section{Amos Setiadi}

Universitas Atma Jaya

Yogyakarta, Indonesia

amos.setiadi@uajy.ac.id

\section{Dwi Astuti Depari}

Universitas Atma Jaya

Yogyakarta, Indonesia

Chatarina.depari@uajy.ac.id

\begin{abstract}
Kauman village becomes a symbol of the Javanese philosophy and the Islamic ideology on which the local society orient their faith. This research aims to find the residential transformation factors and form in Kauman village in Yogyakarta and the characteristic of each object to conserve Kauman village as a constituent element that defines Yogyakarta City's identity. This research method is qualitative - descriptive research using a synchronic approach to present synthetic results from each object and detailed object characteristics conducted in a certain period. All data are collected by doing observation and interviewing second parties. The discussion led to the residential spatial change as an adaptation form of Batik skipper's and Ketib's residence in Kauman village of Yogyakarta. It can be concluded that the identity of the residents as a part of a modern community is gradually more dominant than the desire to reveal their identity as a part of a traditional Javanese community. Nevertheless, Batik skipper's residences retain Javanese architecture and Indische architecture characteristics as a symbo of the social status of the Batik Skipper and Ketib; The space for religious activities is no longer available in Batik skipper's residence. On the contrary, it is available in Ketib's home, where the residents still retain the function of langgar, which is located in the highest privacy zone.
\end{abstract}

KEYWORDS:

Transformation; Residential; Kauman; Islamic; Identity

\section{INTRODUCTION}

Transformation is explained in this study because authors want to highlight the historical value and characteristic of each object in Kauman Village that is transformed by modernization aspects. They also influence the development of the city of Yogyakarta. The finding of this research can help conserving Kauman village as a constituent element that defines Yogyakarta City's identity. Furthermore, both physical and non-physical modernization aspects influence a development paradigm. They also influence the factors driving growth including economic, social, cultural, and political factors. Those factors are the indicators used for assessing the urban development progress. However, the city's product also has negative impact; environmental degradation, displacement of local cultural values, significant socioeconomic disparity, and identity crisis. Yogyakarta is a traditional Javanese city; it has the history and influence of Islam since the 18th century BC. Islam underwent assimilation to the Javanese culture that previously got the Hindu-Buddhist cultural force in the 6th century $B C$.
In addition to their Eastern cultural influence, western culture played a role in determining its development. On the other hand, Javanese culture is open and can integrate with the other cultures; thus, it forms a unique cultural entity. One of the individual cultural entities can be seen in the village called Kauman. Kauman once was under Islam's influence and became a residential area inhabited by Islamic students [1]. In the past, Islamic leaders in the village were in charge of religious activity in the Kraton (Sultan Palace) as Abdi Dalem Pamethakan [2].

The factors that affect spatial changes and residential architecture in the Kauman village are external and internal factors. The external factors include modern architecture on new buildings in the Kauman village; while the internal one is the nature of villagers adapting to the new livelihoods. The adaptation causes adjustments to spatial and residential forms. It is a concern that the changes may change the characteristics of the residential architecture in the Kauman village. The facilities selected to be the research objects are residentials that use Javanese architecture and Islamic architecture criteria. The residential spatial changes of batik skipper (Juragan Batik) and Ketib are essential to study 
because the spatial element and form of the architecture of the Kauman village is the part of Yogyakarta's traditional village's identity. Thus, the result of this study is useful to support the preservation efforts of the historic district.

The purpose of this study is to uncover the transformation seen in the residential houses in Kauman village as a kampong that has the peculiar blend of Islamic and Javanese architecture. The transformation is an essential effort for the regional preservation. This study's novelty value is to find a form of housing adaptation in Kauman village from Islamic to socio-economic changes in the region. This study complements various previous studies, such as:

1. Traditional Javanese House Building in Kauman Village [3]. This paper looks at the connection between the artifacts' findings with the Kauman's settlement and Yogyakarta's palace. The descriptive-analytical method is used to describe and analyze the artifacts to see the development of Kauman itself.

2. Community-Based History Management in Kauman Village [4]. In this case, the Kauman area will serve as a village with a sustainable cultural tradition since the establishment of Ngayogyokarto Hadiningrat Sultanate. Following the living museum concept, many kinds of ideas, obtained from the interviews conducted with Kauman elders, community figures, and young people about the history of Kampung Kauman, will be implemented to regain the old cultural traditions

3. The Unsacred "Cikal Bakal" space in Kauman Village [5]. In her research, Suastiwi found the local spatial theories in the space agreement and secularization as a reflection of Islamic monotheism and devoutness in Kauman. Space agreement and secularization are the purports of space made by the residents, which are built naturally, born from the daily living activities that require the agreement of space and secularized space to obey God's commands and prohibitions as well as to do the righteousness in accordance with their religious beliefs.

4. Kauman Village Community Life [1]. This brief paper is meant to discuss the social and economic life of a united community that lives in the Kauman kampong.

\section{METHODS}

This paper wants to explain spatial changes and residential forms, which the author has not discussed above. The architecture reflects the values of the local community and influences cultural diversity as well. Local matters raise the distinctiveness of architectural forms in each region. Each region's architecture's specificity depends on the response and utilization of environmental resources that reflect humans and nature's relationship. Thus, traditional architecture reflects the cultural variations and the relationship between humans and nature. The residents' psychological needs become a significant factor in the design of architectural space [6]. The factors are associated with how the residents understand the building's shape and area as well as how the room and the facility can meet the residents' needs, and reflect their lifestyle and symbols. As a symbol, the building can be a medium to communicate a person or a particular social group, both consciously and unconsciously. The symbol meaning can be conducted through three approaches; semiotic, symbolic, and non-verbal communication. Semiotics is the sign approach consisting of the signal, the reference (meaning), and the way how it affects human behavior. There are three components in semiotics named the semantics, syntax, and pragmatics [7].

Javanese community who live in Kauman understand the concept of jagad gedhe (macrocosm) and jagad cilik (microcosm), so it takes harmony between nature as the holy spirit, which gives life to a human who must always be grateful by giving offerings to them [8] [9]. Therefore, there is a beliefs telling that the Javanese community has always been guided by one principle, called memayu hayuning bawana, when building houses, which means "trying to beautify the environment and maintain harmony with the surrounding nature [10]. The expression of the belief is also manifested in the pattern of everyday's behavior, religious processions, and Javanese science; it is called Sufism in Islam, such as respecting the spirits by visiting the graves of ancestors in Ruwah. It is a period before fasting, which is also known as nyadran tradition.

From the aspect of social and community relations, there are three groups of Muslims in the cities in Java, namely (a) priyayi and intellectual Islamists who refuse Islamic dogma because it is more concerned with the mystical elements of Java in the local life; (b) santri, the Islamic students who are more concern about Islamic dogma and refuse supernatural doctrine socially although they are closer to the aristocracy than to abangan; and (c) abangan, a group of ordinary people who pay less attention to the Islamic intellectuals and Islamic dogma but is more concerned with Javanese mystical beliefs [11] [12] [13].

In the different Islamic eras, we can focus on many forms of concept, such as the police, society, and economics concept, to ensure and prove that the changes in Islamic architecture are always suited for the concepts of every existing era [14]. In the building, there are indications of change. Transformations occur in the form and spatial layout of buildings. It is apprehensive that the changes could remove the building's characteristics. This article aims to examine the transformation.

The development of the residential spatial of Kauman village was revealed through a synchronic approach as the observation was conducted in a 
certain period. The synchronic approach examined the relationship between aspects resulting from the diachronic, revealing the regular residentials' spatial and change ones [15]. Simultaneously, the typology approach describes the type of layout and the building form to build appropriate adaptations to the changes, style, and elements forming residential space to classify certain kinds of spatial occupancy [16]. The data collection methods are categorized into two types, based on the data collection: primary data obtained from direct observations in the field. Primary data comprise the documentation of façade and layout in the existing site as well as the interview conducted with the residents of Kauman Village. Then, secondary data was obtained from second parties [17]. Book and journal are needed to review historical value and architecture on site.

The method used to manage the primary data is a purposive sampling that include 9 residential houses undergoing significant transformation. The interviews are conducted with the homeowners; they are:

1. Mrs. Yati, Mrs. Yaron, and Mr. Surat, as the owners of colonialism architecture style

2. Mrs. Istinaroh, Mr. Lukman, and Mr. Muhsin, as the owners of the Javanese architectural style, which is also influenced by colonialism architecture

3. Mr. Nahfi, as the Kauman's local architectural style residence, which is influenced by the Colonial and modern architectural elements

4. Mr. Ramayana and Mr. Bajuri, as the owner of modern

The data on the changes in the spatial character and form of 9 buildings are analyzed using qualitative descriptive methods to describe the factor and characteristics of the transformation phenomenon in Kauman Village.

\section{RESULTS AND DISCUSSION REVIEW: KAUMAN VILLAGE}

Kauman is located in the West of the North Square of Kraton (Sultan Palace). The establishment of Kauman village was associated with the history of Kraton (refer to fig 1). There is a mosque in the town. A religious ceremony in the Yogyakarta Kingdom was executed in the courtyard of the Kauman Mosque. Kauman is a settlement of pamethakan who was in charge of the kingdom's religious activities [13] [5].

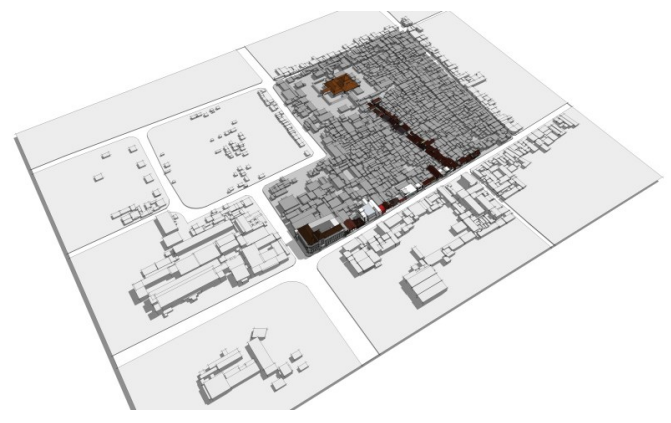

Figure 1. Kauman Viilage, Yogyakarta [18]
As the officials in the Yogyakarta Kingdom's bureaucratic structure, pamethakan obtained a loan in the form of a land plot called gadhuhan around the mosque to be worked on. Pengulu occupied a residential area located in the North of the mosque (Dalem Pengulon) to directly oversee the mosque's existence [4]. Dalem Pengulon functioned as an official office and a place for Pengulu to stay (Kawedanan Pengulon). Kawedanan Pengulon still served as a royal property until now, but the gadhuhan land belongs to Ketib, Modin, Barjamangah, and Merbot have become private properties. In performing its duties, Pengulu was assisted by the subordinate officials called Abdi Dalem Pamethakan, consisting of Ketib, Modin, Barjamangah, and Merbot. Pengulu dealt with religious rituals and the local culture such as marriage, divorce, reconciliation, caretaker of the tomb, naib, and law in religion. It also dealt with the mosque's judicial matter; Ketib served as the preacher of the Friday prayers and religious teaching; Modin was in charge of proclaiming the call to the prayers right before the obligatory prayers; Barjamangah was assigned the duty to pray to qualify the validity of Friday prayers participants; meanwhile, Merbot was in charge of cleaning service and maintenance of the mosque building [3].

The main activity in the Kauman village is associated with the elements of Javanese religion and tradition. However, currently, there is a boost within the Kauman community who wants to develop the town as one of the tourist destinations in Yogyakarta. The purpose has been proposed to the Government of Yogyakarta through the local leaders since 2013. Still, it has not been realized because of the village's feasibility as a historical tourist destination. Kauman village consists of residents with various types of forms. Each type's shape shows a mixture of Javanese architecture elements, Islamic architecture, the Kraton's architecture, and Dutch architecture. The types of residents in Kauman village are divided by the residents' social status category, named: public residential area and residence of the mosque's Pengulu (refer fig 2). Pengulu is a mosque leader in the management of Kauman mosque. Pengulu's home was located in the Northern part of the mosque, consisting of a Pengulon palace (Pengulu's residence) and tepas kawedanan pengulon (Pengulu's office). Kyai Pengulu carries out his duties in the Pengulu's office at the Yogyakarta Kingdom. Kyai Pengulu's residence consisted of three main parts; those were Pendhapa, Pringgitan, and Dalem. Pendhapa functioned as a semicommunal space, as a reception room and meeting place, for example. Meanwhile, Pringgitan was a room that other people could still access, but it was limited. Pringgitan also functioned as a secretariat of tepas kawedanan pengulon, the space for Abdi Dalem (servants) who dealt with the mosque administration. Dalem was partly reserved for the nuclear family of Kyai Pengulu only. Besides, there were buildings on the right side and left side of pendhapa called Gandhok, which functioned as the family or relatives' residence. The small door connecting Gandhok with Dalem was 
called Seketheng.

Abdi dalem's residence was originally intended only for the servants of the palace. In general, the courtiers' role was carried on among the generations and had its settlement named according to the duties or courtiers' work. In this era of globalization, in the end, the village servants' settlements are also inhabited by people of other livelihoods. This, in turn, it makes the palace servants' role as the executor who dealt with cultural preservation is increasingly important, wherein the palace servants later become the role models for the communities living in the area where the servants live. It has a positive impact on the because the role of the servants in the palace can then increase the enthusiasm of the surrounding community to be more concerned about the local culture and participate in preserving it [19]. Javanese Islamic architecture appears to be highly influenced by the previous cultures even though Islam has brought a new civilization since the $13^{\text {th }}$ century in Indonesia [19].

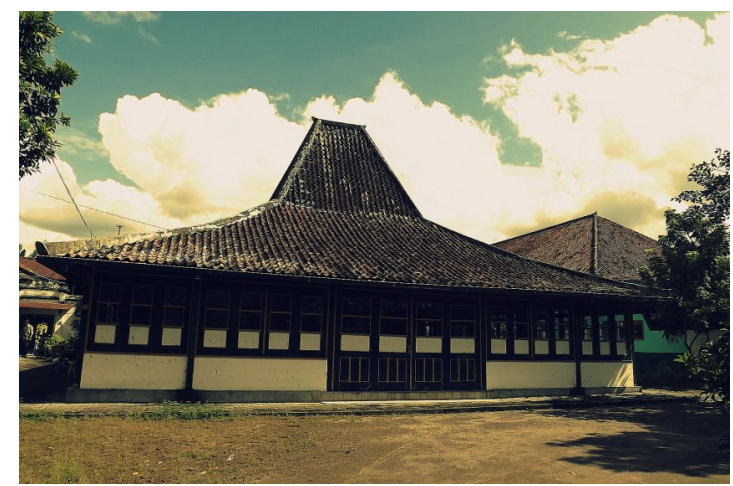

Figure 2. Kyai Pengulu's residence in Kauman Village Yogyakarta [18]

Ketib's residence is a place for the Yogyakarta Kingdom employees who are responsible for providing Islamic preaching during Friday prayers and teachings of Islamic values to the jama'ah (congregation). It is spread over Kauman village. Batik skipper's residential area was once Ketib's residence, which functioned as batik industry and was converted into a boarding house, inn, and house for rent. From 1900 to 1930, the Kauman village communities worked as Abdi dalem (courtiers). Their side jobs were managing batik industry pioneered by Ketib's wives. Batik boomed and produced by several batik entrepreneurs. Batik industrial activity increased the economic welfare of the community in Kauman. The indicator of the increased economic prosperity can be seen from several mansions belong to the batik skippers. The luxurious homes could also be seen from Batik Handel's residence, which generally applies Indisch style. For example, there is a house behind the mosque in Ngindung, the Northern Kauman. The batik Handel's residence still functioned as a resident for the relatives and descendants of the first owner. Most of the dwellings are very well maintained, but some others are not.

Some Javanese principles remain in developing modern houses, namely: (1) a house should always be developed creatively to give comfort and protection; and (2) a house should always give benefit and wealth to the owner [19]. The existence of sacred space creates a strong character. The existence of a sacred space is a form and a medium of religious worship activities and traditions of belief. The influence of the teachings of Islam is enormous in realizing the sacred space, as well as the remnants of Javanese traditions and beliefs that still exist in the life of society. The medium of these activities forms the character of a sacred space that is centered, relatively closed, and vertically transcendental-oriented. Concerning its environment, sacred space is manifested in some stages [20]. Today, heritage is a strategic importance because of its historical value and the capacity to sustain traditional philosophy. However, a problem arose in association with the over-commercialization of heritage that led to a question of how the citizens react to the situation and the emerging values [21].

\section{THE RESIDENTIAL FORM AND SPATIAL TRANSFORMATION}

The batik industry was developed from 1900 to 1930. At that time, most of the Ketib's wives supported the family financially by handling the batik industry in their residences. The domestic industrial activity resulted in different architectures of the houses of Ketibs, who once worked as batik skippers and those who did not. Based on the observation of the Ketibs' residential form and spatial matter, some information were obtained from the residents that there are not many changes or modifications to the buildings. The activities are conducted based on the residents' daily routine, which are mostly and directly regarded as everyday's domestic activities. The condition is different from the Ketibs' residents, who also deal with batik skippers [22]. Although the modern batik industry has replaced the traditional batik industry, the people of Kauman still maintain the batik center. The efforts can be seen from the maintenance of commercial space at a fraction of Batik Skipper's residences even though the process of making batik is no longer executed in their residents. More profitable business opportunities provided by running the boarding houses and house rental promote a residential spatial change of the Batik Skipper. In contrast to batik skipper's residences, the residences of Ketib tend to look as one that maintains the function of the space as a symbol of the social status of the residents, who are the Abdi dalem of Yogyakarta Kingdom (refer to table 1). Spatial adaptation aims to harmonize people and space that will improve social life [23]. 


\section{Table 1. Existing: Residential Spatial and Form [18]}

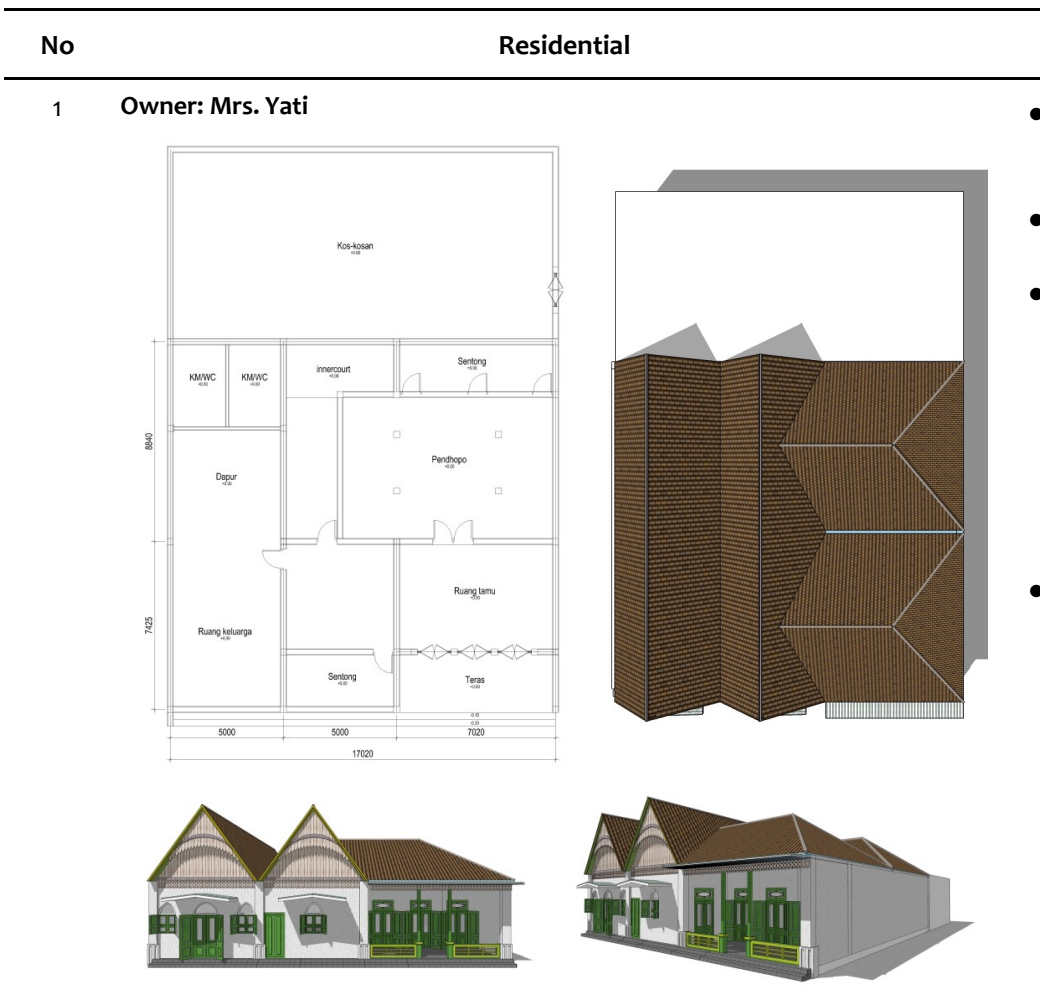

Eksising

- Javanese architectural style, which is also influenced by the colonialism architecture (Indische).

- Overhead Plane: The shape of the roof is a pyramid and gable.

- Vertical Plane: wall, door, and window are featured in Javanese architectural style, made of wood, painted dominantly in green, and have two types of columns with Indische and Javanese architectural style. Javanese traditional ornaments on the building's front wall, guardrail on the porch uses Javanese architecture characterized by green and yellow.

- Horizontal Plane: The floor area is dominated by white.

\section{Owner: Mrs. Yahron}
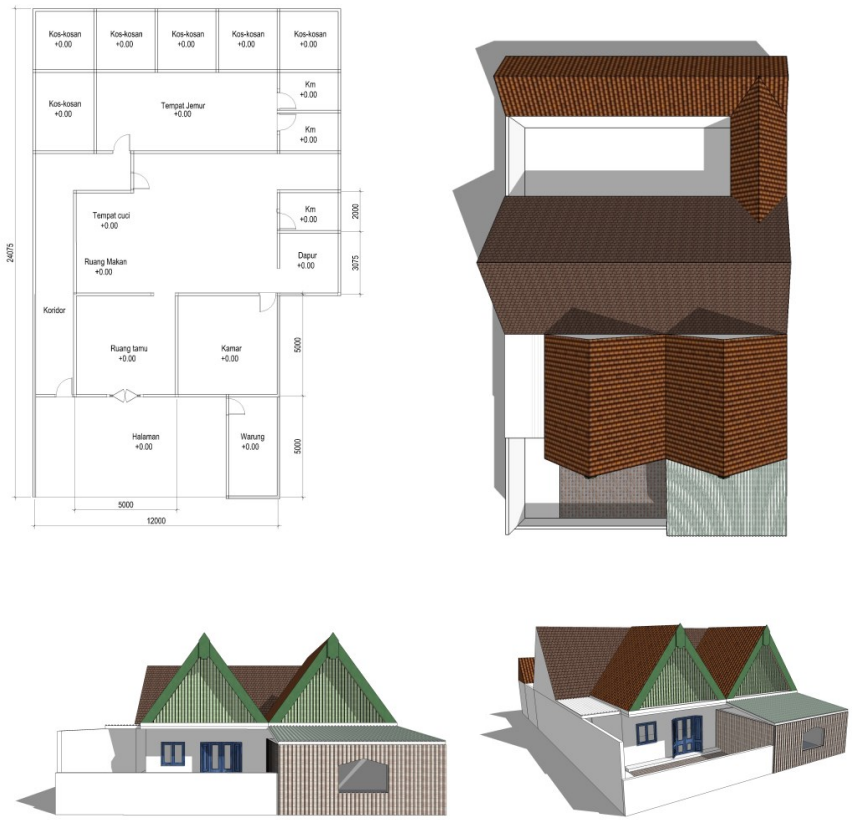

- Javanese architectural style, which is influenced by colonialism architecture (Indische).

- Overhead Plane: The shape of the roof is a pyramid and gable.

- Vertical Plane: wall, door, and window are featured in Javanese architectural style, made of wood, painted in green and yellow, having types of columns with Indische architectural style; a part of a building covered by additional structure functioned as a shop.

- Horizontal Plane: The floor area is dominated by white. 


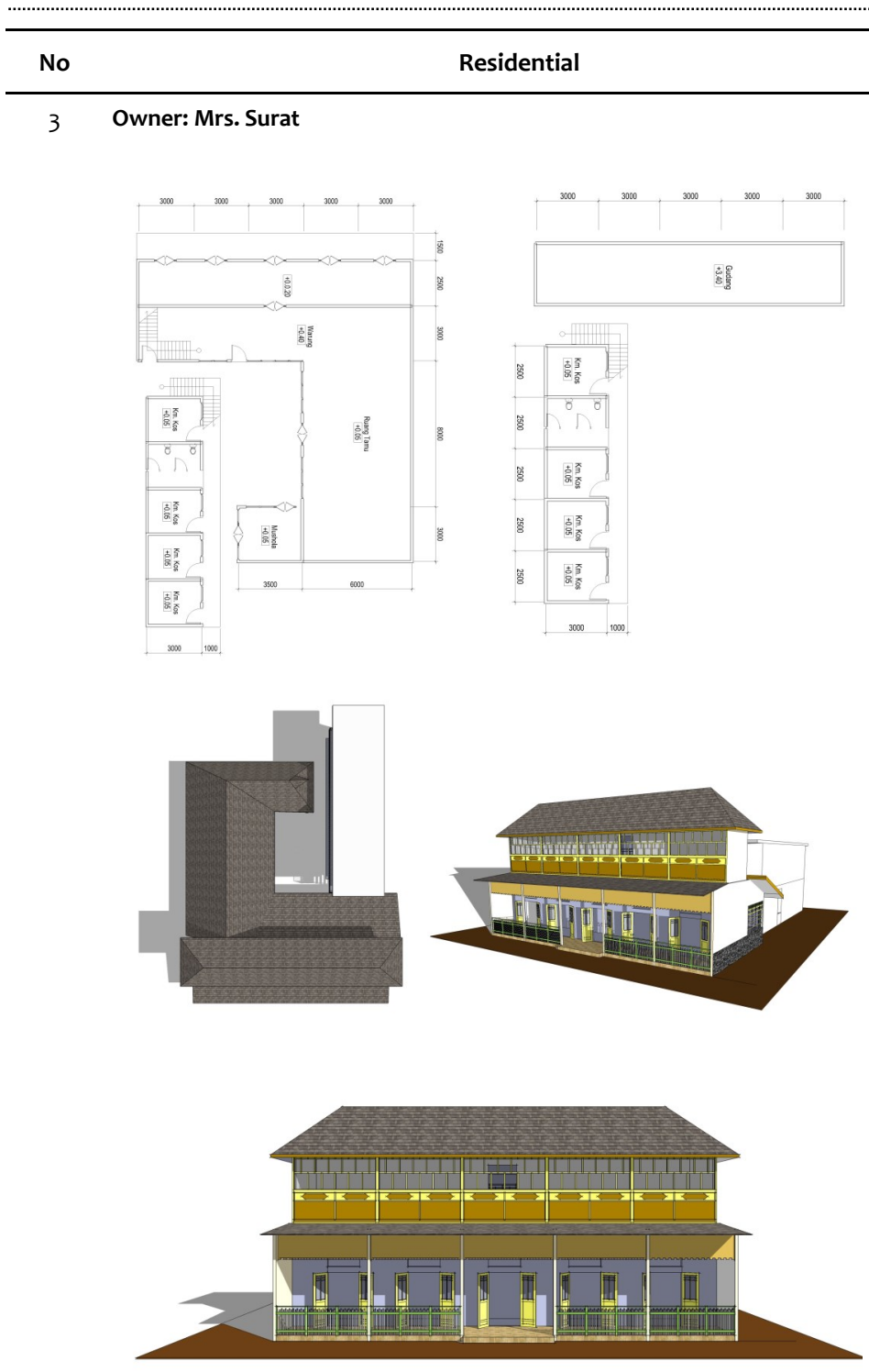

Eksising

- Javanese architectural style, which is influenced by colonialism architecture (Indische).

- Overhead Plane: The shape roof is a pyramid

- Vertical Plane: wall, door, and window are featured in Javanese architectural style, made of wood, and the column type is painted in yellow. There are ornaments on the building's front wall, guardrails on the first and second part are wooden in green, characterized Javanese architecture.

- Horizontal Plane: The floor area is dominated by white.

- Vertical Plane: wall, door, and window are featured in a modern style made of wood material combined with glass, guardrail on the 2nd floor is decorated with stone materials, and vertical wall on the East side featured the contemporary style dominated in pink.

- Horizontal Plane: The floor area is dominated by pink
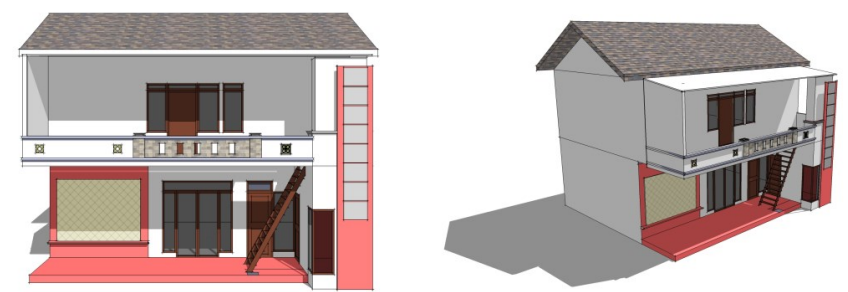


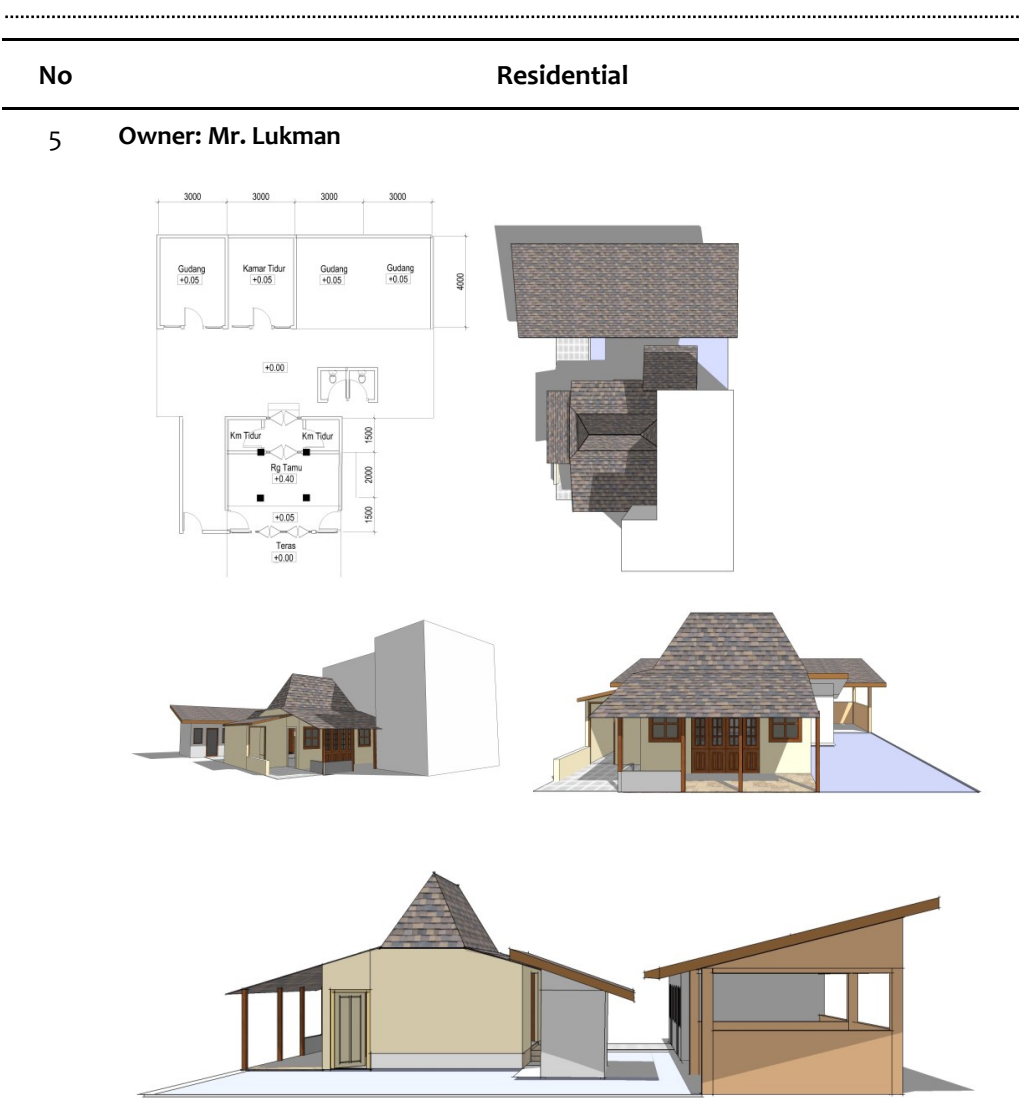

Eksising

- Javanese architectural style, which is under the influence of modern architecture.

- Overhead Plane: The roof is Joglo.

- Vertical Plane: wall, door, and window are featured in Javanese architectural style, made of wood, and the column type is characterized by Javanese architecture with no ornaments. There is a linear-shaped wall on the building's rear side with no decorations on the windows and doors.

- Horizontal Plane: The floor area is dominated by gray.

\section{Owner: Mr. Muhsin}
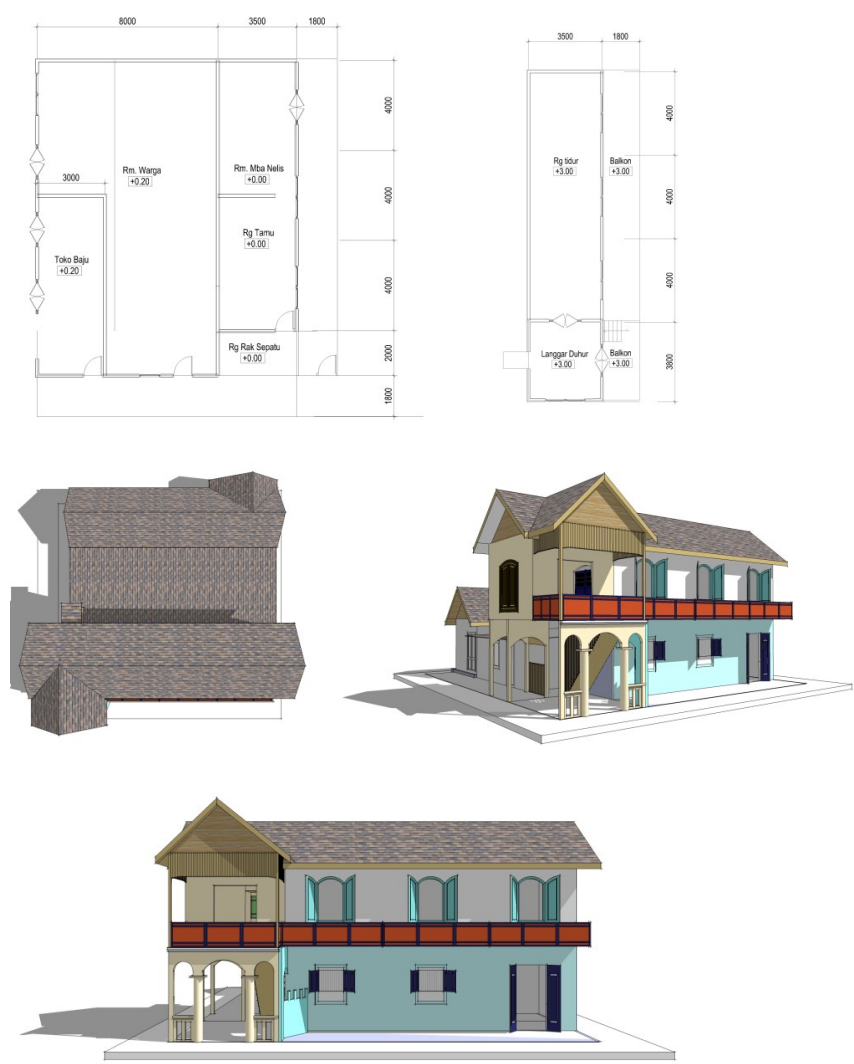

- Javanese architectural style, which is influenced by colonialism architecture (Indische) although Javanese architecture remains dominant.

- Overhead Plane: The roof is pyramid and gable

- Vertical plane walls, doors, and windows are featured in Javanese architectural style. It is made of wood painted in blue. Langgar's column type is a colonial-style column (Indiche). There are ornaments on the railing on the balcony, massive walls with Javanese architectural style in the store on the 1st floor, and ornaments on the roof.

- Horizontal Plane: The floor area is dominated by it. 
Eksising

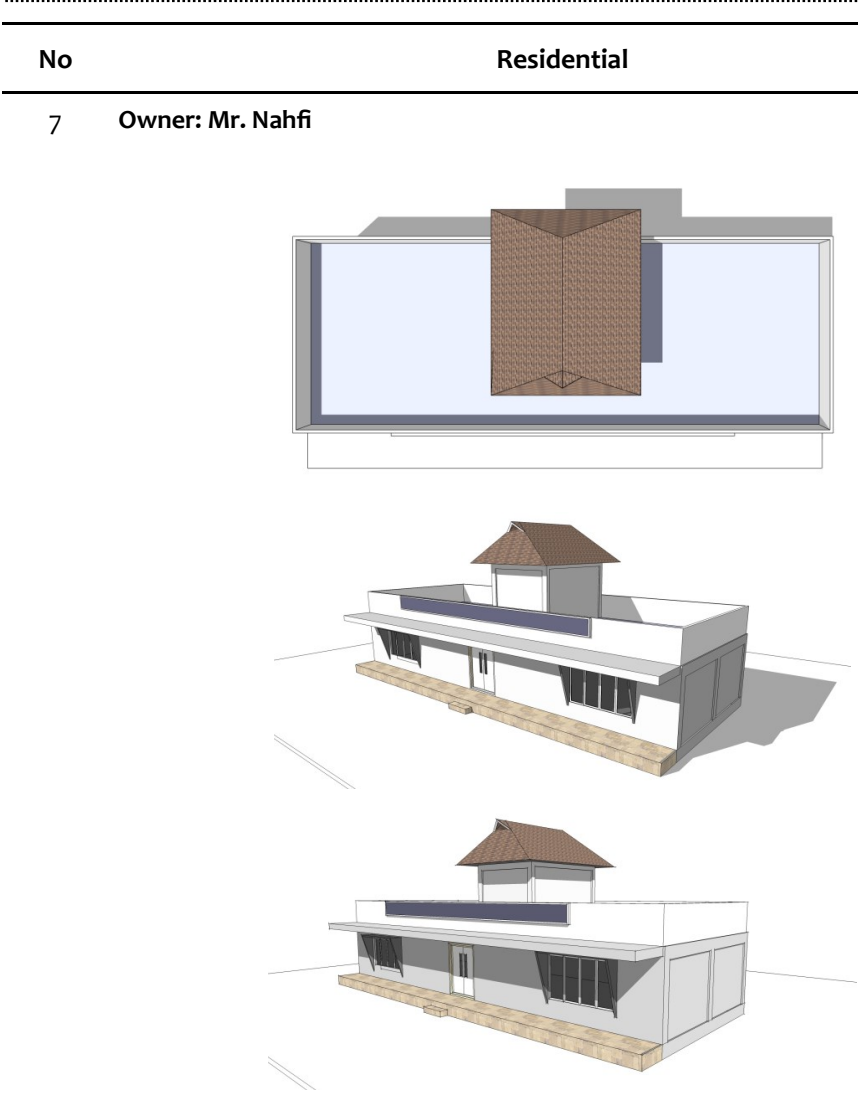

7 Owner: Mr. Nah

8 Owner: Mr. Ramayana
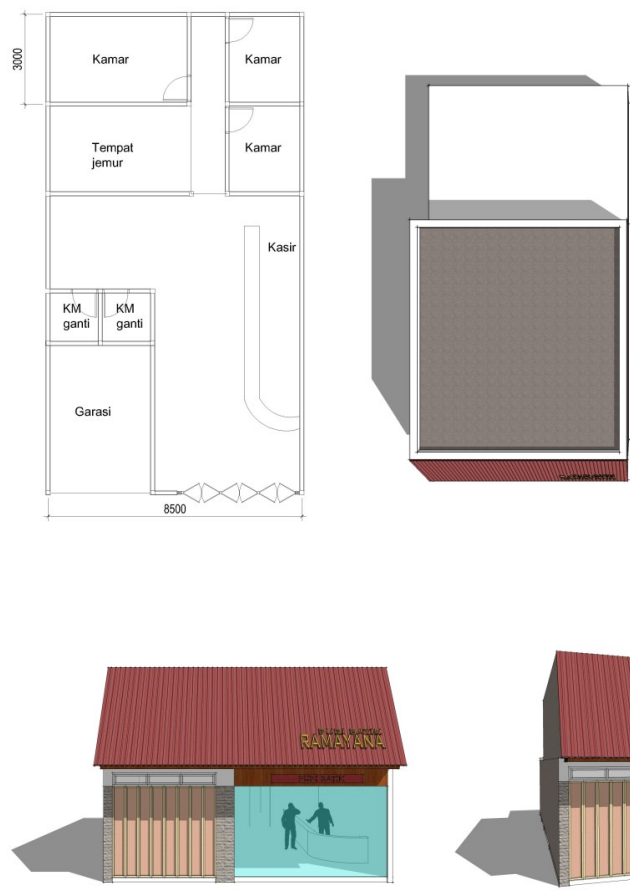

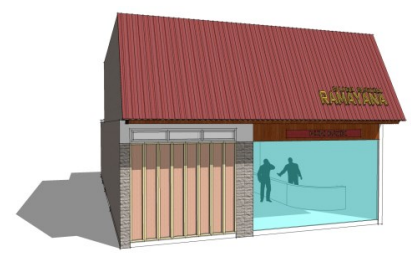

- Kauman's local architectural style residence has gained influence from the Colonial and modern architectural elements with the contemporary image by selecting straight geometric shapes.

- $\quad$ Overhead Plane: The type of limasan roof; partly in the form of concrete dak.

- Vertical Plane: Walls with window openings in modern architecture style that seem very formal; residential area faces walls consisting of repeating window elements on the West and East sides and are divided symmetrically. The color of the walls is dominated by bright colors that increasingly add the residence's formal impression.

- Horizontal Plane: Floor area

- Modern architectural elements have dominated the residential architecture form of Kauman's local architecture. The typology of shophouse building is commonly found in various areas, applied to the residential context of Juragan Batik.

- Overhead Plane: The type of saddle roof.

- Vertical Plane: Walls with the types of glass door openings reflecting modern architecture; folding door types in functional garage rooms, column types of modern-style structures with a touch of ornamental decorative stone arrangements aiming to provide formalities and affirmations impression in the garage room. The decorations on the front walls and guardrails characterized Kauman architecture are not applied on the residential design.

- Horizontal Plane: Floor area 
Table 2. The Transformation of Residential Spatial and Form [4]

\begin{tabular}{|c|c|}
\hline Spatial and Form & Adaptation Pattern \\
\hline $\begin{array}{l}\text { Owner: Mrs. Yati } \\
\text { The room's function supported the daily activities commonly found in } \\
\text { one residence: bedrooms (sentong), family rooms, and living rooms. } \\
\text { Social movements and interactions with guests/relatives generally } \\
\text { take place in pendhapa. Business activities taking place in this } \\
\text { residence express the residents' open attitude towards the migrants. } \\
\text { The transition of activities occurred from batik business activities that } \\
\text { initially took place in the back side of the residence (open space), and } \\
\text { it is now built into a boarding house business center. The strong } \\
\text { influence of the family life of Kraton Yogyakarta is a result of the } \\
\text { Kauman people's status as Abdi Dalem Pamethakan. Western/Dutch } \\
\text { culture was quite dominant in the } 1900 \text { s era, forming the Kauman } \\
\text { people's perception. One's social status is also determined by the } \\
\text { closeness between local people/Yogyakarta and the Dutch. The social } \\
\text { group of the residents is Abdi Dalem Pamethakan, especially Ketib. }\end{array}$ & $\begin{array}{l}\text { - Facing the growing cultural phenomenon in Kauman Yogyakarta, } \\
\text { residents are open to migrants. It also captures business } \\
\text { opportunities by opening boarding houses in the residence's } \\
\text { back side. } \\
\text { - Limited access to the boarding house area and reflection of the } \\
\text { residential owner's substantial control of the boarding tenant's } \\
\text { activities are also intended to protect the residents' privacy from } \\
\text { disturbances originating from the boarding area. } \\
\text { - The spaces that survive as the shaper of residential identity are } \\
\text { sentong and pendhapa rooms. } \\
\text { Simultaneously, boarding houses' existence shows a pattern of } \\
\text { residents' adaptation to life demands in the present context. The } \\
\text { strong influence of the general view when the Indische building } \\
\text { symbolized the occupants' social status/owners is relatively high } \\
\text { in the middle of the Kauman community. } \\
\text { A system of arrangement of wooden layers as ornaments on the } \\
\text { roof wall, the shape of windows and doors that reflect Javanese } \\
\text { village's architecture, and the intense yellow, green color on the } \\
\text { columns and window door openings are symbols of Kraton and } \\
\text { Islam architecture. }\end{array}$ \\
\hline
\end{tabular}

\section{Owner: Mrs. Yahron}

The transition of activities occurred from batik business activities that The spaces that survive as the shaper of residential identity are initially took place in the back side of the residence (open space) and residential supporting rooms such as the living room area, bedroom, now switched functions as a business room for rented rooms. On the kitchen, dining room, yard, laundry room, and bathroom. The strong social aspect, the boarding business activities in this residence influence of the general view when the Indische building symbolized express the mindset of residents who are now open to the presence the occupants' social status/owners is relatively high in the middle of of migrants. Therefore, economic or business activities consist of 2 the Kauman community. Thus, there is a combination of Kauman and parts: the boarding business in the back side and the warung business Colonial architectural culture on residential buildings' front faces. in the residence's front room.

Adjustment to the present's needs is responded by building mass buildings/commercial spaces that are close to the residence's front face to disrupt the visual continuity and architectural characteristics of Kauman residence. 


\section{Owner: Mrs. Surat}

The strong influence of the family life of Kraton Yogyakarta is due to the status of Kauman residents as servants or Abdi Dalem Pamethakan, especially as Ketib. The transition of activities occurred from batik business activities that initially took place in the back side of the residence (open space) and is now built as a business center for boarding houses. The strong influence of modern life and today's life demands the influence of the residents' mindset reflected through commercial space located on the East side of the building. Social interactions that are semi-public and semi-private can be performed on the building's 1st floor, such as living rooms, prayer rooms, and food stalls.

\section{Owner: Mrs. Istinaroh}

It is a dominant influence of the mindset and outlook of life on the The strong influence of modern elements is shown by the building's occupants' activity system today. The actions of residents preferences of building owners who adopt today's architectural style. are centered on the daily life routines of the residents. The attitude Local architectural features are only reflected through the selection and mindset of the residential owners who are very open to today's of residential roof designs. The symbol of the adaptation pattern is views and perspectives reflect a shift in meaning and perception of shown through selecting the color of the building, the shape of the housing, especially in Kauman village, Yogyakarta.
The condition shows a change in residential and batik business function to the business' operation through renting a boarding room. Residential spaces have changed or switched roles into boarding rooms and areas that support the tenants of the boarding house's daily activities. There is no function of residential identity-forming rooms that remain. opening elements of doors and windows, and ornaments of the Kauman buildings that are missing / not applied

\section{Owner: Mr. Lukman}

It is a very dominant influence of the mindset and outlook of life on The adaptation pattern is made by building a bedroom and the building's occupants' activity system today. The actions of warehouse facilities in the central residential building's back side. The residents are centered on the daily life routines of the residents. The strong influence of modern elements is shown by the preferences of attitude and mindset of the residential owners who are very open to building owners who adopt today's architectural style. The symbol of the elements of view and perspective today reflect the shift in meaning and perception of housing, especially in Kauman village, Yogyakarta

dhe building dominated by white elements, the shape of the opening components of doors and windows, and ornaments of Kauman buildings that are missing/not applied.

\section{Owner: Mr. Muhsin}

The strong influence of Kraton Yogyakarta is due to the residents' Facing the growing cultural phenomenon in Kauman Yogyakarta, status as servants or Abdi Dalem Pamethakan, especially Ketib. Their residents remain resistant to maintaining housing function by the daily activities are centered on religious and cultural fields. A owner's social status and his ancestors as Ketib. Adaptation is made powerful kinship system dominates this residence. The mass group of by keeping most of the parts of space and the relationship between buildings is also inhabited by the closest relatives of the owner's the original areas. Most of the space's functions are intended to family. Economic activity also affects the order and function of support the daily activities of owners and relatives of families. The residential spaces. Some residences function as commercial spaces, adaptation pattern to the change in the occupants' orientation is places to sell clothing needs. indicated by the commercial space on the Westside building.

\section{Owner: Mr. Bajuri}

It is a very dominant influence of the mindset and outlook of life on The adaptation pattern is made by building a bedroom and the building's occupants' activity system today. The actions of warehouse facilities in the central residential building's back side. The residents are centered on the daily life routines of residents. The strong influence of modern elements is shown by the preferences of attitude and mindset of the residential owners who are very open to the building owners who adopt today's architectural style. The the elements of view and perspective today reflect the shift in symbol of the adaptation pattern is shown through selecting the meaning and perception of housing, especially in Kauman village, Yogyakarta.

building's color that is dominated by white elements, the shape of the opening components of doors and windows, and ornaments of Kauman buildings.

\section{Owner: Mr. Nahf}

The attitude and mindset of residential owners who are very open to Adjustments to today's needs and trends are responded to in the the elements of view and perspective today reflect the shift in building's architectural design level. The symbol of the adaptation meaning and perception of housing, especially in Kauman village, pattern is selecting the color of the building dominated by white Yogyakarta. Considering the residence's initial function that also elements, the shape of the opening components of doors and serves as a batik craft room, with the loss of batik activities in the windows, and ornaments of Kauman buildings that are missing / not dwelling, there has been a transition or change in the dwelling's applied function.

\section{Owner: Ramayana}

Economic activities that support the daily life of building owners There are no spaces that survive as a form of residential identity dominate the function of housing. Sold clothes are the clothes made unless a bedroom that is concentrated in the residence's back side. from Kauman batik handicrafts, but the work process no longer takes One of the crucial rooms that symbolizes its function as a residence place in the residence as the initial condition. Social activities and of Juragan Batik in the past is the existence of batik-making zones interactions are not housed in residential areas, given the limitations consisting of batik-making rooms and batik washing/drying rooms. of the land. Based on the interviews conducted with the owner, the Most residential spaces have been converted to build garages and private zone is intended only for its next kin. The activities shopping/commercial spaces.

transitioned from, initially, concentrating on making batik to selling

batik handicraft products ready for sale. 
The floor plan of residential buildings adopted the types of clustered form space organizations as the dominant pattern and types of relationships between spaces that intersect. Generally, in Juragan Batik's house, the function of living space switches to a rental/ boarding house business with the division of the owner's private space zone in the front area of the site and the cost in the yard/back side occupies a former yard/open space for batik process activities in the past. Simultaneously, the commercial area is placed in the residence's front room close to the public lane/ street-the private residential space in the home's back side to obtain the highest privacy. Thus, the function of space to accommodate religious activities is generally no longer applied to Juragan Batik's residences, in contrast to Ketib's residences that maintain the planned breach/placed position in zones with a high privacy level.

The building's architectural design that undergoes the most significant modification is the type of Juragan Batik's residence, especially in residential areas where the entire activities are used for shops. The Juragan Batik's house residents' improvements are concentrated on utilizing backyards that were previously intended for the process of making batik into a boarding area/rental house. Still, one residence, Juragan Batik, undergoes a radical modification because clothing sales activities dominate its designation. In the Ketib's residence, Kauman's architectural characteristics remain dominant even though it has facilitated new functions by selling space. The maintained space function on the 2nd floor is broken. Since the beginning, the absence of yard area has been intended for batik activities as what can be seen in the residence of Juragan Batik or batik makers. Elements forming the residential identity of Juragan Batik are seen in the buildings that adopt Colonial architecture and modern architecture elements. There are minimal ornaments, except in 4 dwellings, that still maintain the original architecture of Kauman; while, in the Ketib's residence, there is a fence placed on the 2nd floor of the home by adopting Kauman architecture with little influence from the colonial architectural element.

Based on the analysis carried out on the adaptation patterns of the occupants of Juragan Batik's and Ketib's buildings, conclusions can be obtained related to the study carried out both on the aspects of the habit of indoor space order with the architectural design of Juragan Batik's and Ketib's residential buildings, namely:

1. The Influencing Factor on The Adaptation Process of Juragan Batik's House and Ketib's in Kampung Kauman Yogyakarta

a. Socio-Political and Cultural:

- There is still a strong influence on the family life of Kraton Yogyakarta due to the status of Kauman residents as servants or Abdi Dalem Pamethakan. However, identified some residences whose orientation leads to the cultural values of today.
- Western/Dutch culture was quite dominant in the 1900s, thus forming the perception of Kauman people that one's social status is also determined from the closeness between local people / Yogyakarta and the Dutch.

- The influence of current mindsets and outlooks on the activity system of building residents.

b. Economy

The business transition from batik handicrafts gradually faded was replaced by more profitable business ventures such as boarding and rental houses, Kauman batik apparel stores, and food stalls.

c. Spiritual/Religious

Of the 9 (nine) Juragan Batik's and Ketib's residences studied, only 1 (one) Juragan Batik's residences facilitate religious rituals by providing Musholla buildings used jointly by residents' boarding tenants placed in transitional spaces. In the Ketib's residence, the function of breaking remained to build the sacredness of the worship room.

2. Adaptation Pattern of The Residents of Juragan Batik's and Ketib's House

a. The pattern of Indoor Space Order :

- Facing the cultural phenomenon that develops in Kauman Yogyakarta, residents are open to migrants and capture business opportunities by opening a commercial area in a typical Kauman batik clothing store. In addition, the residence's front room or boarding house and rental house are placed in the residence's backyard area, especially in the type of Juragan Batik's residence.

- Limited access to private areas reflects substantial control of residential owners towards activities derived from semi-public store space.

- There are no spaces that survive as the shaper of Juragan Batik's residence's identity is symbolized by elements in the form of open space as a batik-making zone consisting of batik-making room and batik washing/drying room. However, most residential areas have been converted to build business and commercial spaces.

b. Residential Architectural Design

- The strong influence of modern elements is demonstrated by the preferences of building owners who adopt contemporary architectural styles and are combined with local architectural styles (Kauman)

- Adaptation efforts that still maintain the characteristics of local architecture are generally reflected through the selection of local residential roof designs that remain dominant; limasan roof, pelana, and Joglo roof, the choice of the dominant green color as a form of palace architecture quality, the shape of window openings and doors that seem formal, repetitive and made of wood, ornaments on the roof in the form of rows of 
wooden panels that cover part of the facade of residential roof walls, ornaments on the guardrails in the patio and balcony, slender columns made of wood on the mass type of building, Colonial-era efforts to adapt to the importance and power of the elite of the Dutch Colonial colonial era through modifications of local architecture with Colonial architecture (Indische architecture) symbolized through the design of column shapes and arcades on the facade of the front of the residence.

- Responded to the selection of glass and concrete materials, ornamental stone ornaments on walls and columns, the shape of doors and windows that characterize modern tropical architecture, concrete dak roof, dominant white color or contrast/ light colors follow the tastes of residents.

- The identity of residents as part of a global community is gradually more dominant than the desire or motivation to show its identity as part of the Kauman Yogyakarta community. Nevertheless, there are still Juragan Batik residences that still maintain the architectural characteristics of Kauman and Indische as a symbol of the social status of the Batik Juragan and Ketib.

While the identity-forming elements of Juragan Batik's and Ketib's residential buildings can be grouped into two categories, namely:

1. Aspects of Spatial Order Patterns in Juragan Batik's and Ketib's Residence

a. On the residential building plan adopts the type of clustered form space organization as the dominant pattern of space organization to intersect inter-space relationships.

b. Generally, in Juragan Batik's house, the living room and batik industry center's function turned into a business room rental house/ boarding house.

c. The building zone division is the owner's private space in the front area of the site, while the boarding area in the yard/ back side occupies a former yard / open space for batik process activities in the past.

d. Commercial area is placed in the residence's front room relatively close to the public lane/ street, while the private residential space is placed in the home's back side to obtain the highest privacy.

e. The function of space to accommodate religious activities is generally no longer applied to Juragan Batik's residences, in contrast to Ketib's residences that maintain the planned breach/placed position in zones with a high level of privacy.

2. Aspects of Architectural Design of Juragan Batik's and Ketib's Residence

a. The building's architectural design that undergoes the most significant changes or modifications is in the type of Juragan Batik's residence, especially in residential areas whose entire activities are used for selling/shops.

b. Modifications made by the Juragan Batik's house residents are concentrated on utilizing the backyard previously used for the process of batik into a boarding area and rental house. Still, there is one residential building of Juragan Batik that has undergone a radical modification because its designation is dominated for selling activities or as a clothing store.

c. In the case of the Ketib's residence, Kauman architectural design characteristics remain dominant even though it has accommodated new functions by providing selling rooms/ shops.

d. The function of the space maintained in the Ketib's residence is a breach on the building's 2nd floor. The absence of open space since the beginning of batik development is intended to make batik. Therefore, it is found in the ketib's residences working as Batik Juragan or Kauman batik makers.

e. Elements that shape the residential identity of Juragan Batik are buildings that adopt elements of Colonial architecture and modern architecture. Minimal ornaments except on four dwellings that still maintain the original architecture of Kauman while in the Ketib's residence, there is a fence placed on the 2nd floor of the home by adopting Kauman architecture with little influence from the colonial architectural element.

Based on the analysis carried out on the pattern of adaptation of the occupants of Juragan Batik's and Ketib's buildings, conclusions can be obtained related to the study carried out both on aspects of the habit of indoor space order with the architectural design of residential buildings of Juragan Batik and Ketib, namely:

A. Influence Factor on The Adaptation Process of Juragan Batik's and Ketib's House in Kampung Kauman Yogyakarta

a. Socio-Political and Cultural:

- There is still a strong influence on the family life of Kraton Yogyakarta due to the status of Kauman residents as servants or Abdi Dalem Pamethakan. However, some residences having an orientation that leads to today's cultural values are identified.

- Western/Dutch culture was quite dominant in the 1900s; thus, it formed the perception of Kauman people. One's social status is also determined by the closeness between local people/Yogyakarta and the Dutch.

- Today's mindset and outlook influence on the activity system of building residents.

b. Economy

A business transition from batik handicrafts has gradually faded, and it was replaced with more profitable business ventures such as boarding houses and rental houses businesses, Kauman's batik clothing 
stores, and food stalls.

\section{c. Spiritual/Religious}

Of the 9 (nine) Juragan Batik's and Ketib's residences studied, only 1 (one) Juragan Batik's residence that facilitate religious rituals by providing Musholla buildings, which is used jointly by the residents' boarding tenants placed in transitional spaces. The function the Ketib residence remains to build privacy and sacredness of the role of the worship room.

B. Adaptation Pattern of The Residents of Juragan Batik's and Ketib's House

a. Pattern of Indoor Space Order

- Facing the cultural phenomenon that develops in Kauman Yogyakarta, residents are open to migrants and capture business opportunities by opening a commercial area.

- Limited access to private areas reflects substantial control of residential owners towards activities derived from semi-public store space.

- There are no spaces that survive as the shaper of Juragan Batik's residence's identity is symbolized by elements in the form of open space as a batik-making zone consisting of batik-making room and batik washing/drying room. However, most residential areas have been converted to build business and commercial spaces.

b. Residential Architectural Design

- The strong influence of modern elements is demonstrated by the preferences of building owners who adopt contemporary architectural styles, which is combined with local architectural styles (Kauman).

- The adaptation efforts that still maintain the characteristics of local architecture are generally reflected through the selection of local residential roof designs that remain dominant, namely limasan roof, pelana, and Joglo roof. It is obvious that the choice of the dominant green color is a form of the palace architecture quality, the shape of window openings and doors seem formal, repetitive and made of wood, ornaments on the roof are in the form of rows of wooden panels that cover part of the facade of residential roof walls, ornaments are also seen on the guardrails in the patio and balcony rooms, and the slender columns are made of wood on the mass buildings type.

- The efforts to adapt to the prestige and influence of the elite of the Dutch in the colonial era were reflected through the modification of local architecture with Colonial architecture (Indische architecture) as symbolized by the design of column shapes and arcades on the facade of the front of the residence.

- The efforts to adapt to today's trends are responded to through the selection of glass and concrete materials, ornamental stone ornaments on walls and columns, the shape of doors and windows that characterize modern tropical architecture, concrete dak roof, and dominant white color or contrast/ light colors that follow the tastes of residents.

- The residents' identity as a part of the global community is gradually more dominant than the desire or motivation to show their identity as a part of the Kauman Yogyakarta community. Nevertheless, Juragan Batik's residences that still maintain the architectural characteristics of Kauman and Indische as a symbol of the social status of Juragan batik and ketib still exist. The signs of the adaptation pattern is generally comprehended through the form of building architecture, selection of column and arcade designs, choice of colors and building materials, the shape of elements of door and window openings and guardrails on the terrace and balcony on the 2nd floor, and Kauman ornaments that are usually applied to the roof of the facade of the front residence. Whereas, the identity-forming elements of the residential buildings of Juragan Batik and Ketib can be grouped into two categories, namely:

3. The aspects of Spatial Order Patterns in Juragan Batik's and Ketib's Residences

a. The floor plan of residential buildings adopt the type of clustered form space organization as the dominant pattern of space organization to intersect inter-space relationships.

b. Generally, in Juragan Batik's house, the living room and batik industry center's function turned into a business, room rental /boarding house.

c. The distribution of building zones relates to the owner's private space in the site's front area. In contrast, the boarding area in the yard/back side occupies a former courtyard/open space for batik making activities in the past.

d. Commercial area is placed in the residence's front room, relatively close to the public lane/street, while the private residential space is placed in the home's back side to obtain the highest privacy.

e. The function of space to accommodate religious activities is generally no longer applied to Juragan Batik's residences, in contrast to Ketib's residences that planned/placed in zones with a high level of privacy.

4. Aspects of Architectural Design of Juragan Batik's and Ketib's Residence

a. The building's architectural design that undergoes the most significant changes or modifications is the Juragan Batik's residence type, especially in residential areas where the entire activities deal with selling/shops.

b. Modifications made by the Juragan Batik's house residents are concentrated on utilizing the backyard, which was previously used for the batik 
making activities but turned into a boarding house area. Still, one residential building, Juragan Batik's, has undergone a radical modification because its designation is dominated for selling activities or as a clothing store.

c. In the case of the Ketib's residence, Kauman's architectural design characteristics remain dominant even though it has accommodated new functions by providing rooms for selling activities/ shops.

5. Elements that shape the residential identity of Juragan Batik are in the form of buildings that adopt Colonial architecture elements and modern architecture. The minimal ornaments, except on four dwellings, still maintain the original architecture of Kauman; while, in the Ketib's residence, there is a fence placed on the 2nd floor of the home by adopting Kauman architecture with little influence from the colonial architectural element.

\section{CONCLUSION}

The discussion conducted on the residential spatial change as an adaptation form of Batik skipper's and Ketib's residence in Kauman village of Yogyakarta can be concluded as follows: The factors contributing to Batik Skipper's and Ketib's spatial change are SocioPolitical and Cultural Factors (residential orientation partly led to the modern culture values), Changes in the business of batik that is now gradually diminished, the replacement with more profitable business ventures such as boarding house and house rental business, batik clothing stores and food stalls which cause residential spatial and form change, there is only one batik skipper's residence that is used for religious activities.

Moreover, the spatial matter and form characteristics are (1) Batik Skipper's and Ketib's Residential Spatial Changes are open to newcomers and, they are used as business opportunities by having a commercial area in the form of Kauman typical batik clothing store located in the front of the residence or boarding house and house for rent in the backyard of the Batik skipper's place. (2) Limited access to the private area reflects the residence owner's substantial control of the store's activities, a semi-public space. (3) There are no spaces preserved to form the batik skipper's residence identity, which is symbolized by having open space to make batik that consists of washing and drying. (4) Most of the areas have been converted to new functions for business and commercial ones. (5) Modern architecture's strong influence is shown in the building owners' preference for adopting the contemporary architecture style and hybridizing it with the Javanese architectural style. (6) Spatial and residences form's adaptation efforts are partially conducted by maintaining Javanese architectural features such as roof, using green as the dominant color, windows, doors, and ornaments on the roof in a row of wooden panels covering the part of the residence's facade.

Maintaining Javanese architectural features is demonstrated by selecting the traditional Javanese roof, which is dominant to keep, tajug, limasan, and Joglo. Green is the dominant color that forms typical Javanese architecture quality used by the Yogyakarta Kingdom. The shape of the windows and doors seem formal, seems repeated and uses wood materials. The ornaments found on the roof in a row of wooden panels cover the part of the residence's facade. In addition, there are ornaments on the guardrail of the patio and balcony and stylish slender columns featured in Javanese architecture.

\section{REFERENCES}

[1] S. Sairin, "Kauman: A moslem neigborhoood in Yogyakarta," Humaniora, vol. 8, no. Juni, pp. 6771, 1998.

[2] A. Setiadi, Arsitektur Kampung Tradisional di Yogyakarta, Yogyakarta: PT Kanisius, 2010.

[3] M. Chawari, Bangunan Rumah Tradisional Jawa di Kampung Kauman Yogyakarta, Magister Thesis, Yogyakarta: Universitas Gadjah Mada, 2008.

[4] N. A. Setiawati, "Manajemen Sejarah Berbasis Komunitas: Pengembangan Kawasan Kauman sebagai Living Muesum," Bakti Budaya, vol. 1, no. 1, pp. 102-121, 2018. doi: https:// doi.org/10.22146/bb.37934

[5] D. S. S. Suastiwi Triadmodjo, "Desakralisasi Ruang Cikal Bakal di Permukiman Kauman Yogyakarta: sebuah perubahan makna ruang permukiman tradisional di Kota," Jurnal Manusia dan Lingkungan, vol. 16, no. 3, pp. 141152, 2009. doi: https://doi.org/10.22146/jml.18701

[6] A. J. C. James C. Snyder, Introduction to Architecture, New York: McGraw-Hill, 1979.

[7] A. Rapoport, Human Aspects of Urban Form Towards A Man-Environment Approach to Urban Forms and Design, London: Pergamon Press, 1977.

[8] M. Sutrisno, Paradigma Kultural Masyarakat: Teori-teori Kebudayaan, Yogyakarta: PT Kanisius, 2005.

[9] N. Mulder, Di Jawa: Petualangan Seorang Antropolog, Yogyakarta: PT Kanisius, 2007.

[10] F. Bachtiar, Dynamics of Meaning Relation Functions and Forms Architecture Residential Communities Coastal, Ph.D. Thesis, Bandung: Pascasrjana Universitas Katolik Parahyangan, 2013.

[11] D. Lombart, Nusa Jawa Silang Budaya, Kajian 
Sejarah Terpadu, Jakarta: PT Gramedia, 1996.

[12] B. S. Budi, "A Study on The History and Development of The Javanese Mosque," Journal of Asian Architecture and Building Engineering, vol. 4, no. 1, pp. 1-8, 2005, doi: https://doi.org/10.3130/jaabe.4.1

[13] M. Zahnd, Model Baru Perancangan Kota yang Kontekstual, Yogyakarta: PT Kanisius, 2008.

[14] U. N. Ayat Ali., "Architecture in the Islamic Civilization: Muslim Building or Islamic Architecture," Journal of Islamic Architecture, vol. 2, no. 2, pp. 52-59, 2012. doi: DOI: 10.1886o/ jia.v2i2.2202

[15] K. Adimiharja and Salura, Arsitektur Dalam Bingkai Kebudayaan, Bandung: Floris Press, 2008.

[16] C. Alexander, A Pattern Language: Towns, Buildings, Construction, USA: Oxford University Press, 1977.

[17] D. W. Linda N Groat, Architectural Research Methods, John Wiley \& Sons, 2002.

[18] C. D. A. Depari, Artist, Location of Kauman Viillage in Yogyakarta. [Art]. Universitas Atma Jaya Yogyakarta, 2018.
[19] L. J. T. Aurelia Wipranata, "The Influence of Yogyakarta's Philosophical Axis on City Spatial," Advances in Social Science, Education and Humanities Research, vol. 478, pp. 277-283, 2020. doi: https://doi.org/10.2991/ assehr.k.201209.040

[20] N. C. Idham, "Javanese Islamic Architecture: Adoption And Adaptation of Javanese and Hindu-Buddhist Cultures in Indonesia," Journal of Architecture and Urbanism, vol. 45, no. 1, p. 9-18, 2021. doi: https://doi.org/10.3846/ jau.2021.13709

[21] B. S. T. W. M. Untung Joko Cahyono, "Transformation of form in the growth of modern Javanese house in Laweyan Surakarta," Journal of Architecture and Urbanism, vol. 41, no. 4, pp. 288-295, 2017, doi: https://doi.org/10.3846/20297955.2017.1411848

[22] A. R. H. Agung Budi Sardjono, "Sacred Space in Community settlement of Kudus Kulon, Central Java, Indonesia," in IOP Conf. Series: Earth and Environmental Science, Semarang, 2017.

[23] W. I. R. Johannes Parlindungan Siregar, "Rethinking the Heritage Value from Different Perspectives, Case Study in Yogyakarta," International Journal of Architecture and Planning, vol. 8, no. 2, 2020, doi: https:// doi.org/10.15320/ICONARP.2020.124 